бильного материального обеспечения. Большинство респондентов не обладают информацией об особенностях военной деятельности, в том числе о специфических чертах службы в армии на контрактной основе.

Ключевые слова: психологическая готовность к деятельности, социально-психологическая готовность призовника, военная служба по контракту, срочная военная служба, профессионально-психологический отбор.

\author{
Svitlana Fedorenko, \\ PhD (Candidate of Historical Sciences), associate professor, \\ Department of Psychology, Pedagogy and Philosophy, \\ Anna Kovalenko, \\ $5^{\text {th }}$ year student, Faculty of Psychology, \\ Kremenchuk Mykhailo Ostrohradskyi National University, \\ 20, Pershotravneva Str., Kremenchuk, Ukraine
}

\title{
FEATURES OF PSYCHOSOCIAL READINESS OF RECRUITS FOR MILITARY SERVICE
}

Due to the military conflict in the East of Ukraine one of the most important issues of the modern Ukrainian society is the country's defense capacity. Therefore, the issue of creating a capable army is one of the priorities in state policy today. An important component of this process is the increasing of the level of recruits' professional and psychosocial readiness for military service, which can be forced or volunteer. The review of foreign researches has helped to reveal that the level of psychosocial readiness among the young men accepted for volunteer (contract) military service is much higher than that of those enrolled for forced military service. Psychological motivation of the men who volunteered for military service differs fundamentally from the motivation of recruits who execute military duty forcibly. An important component of the successful and psychosocial readiness of today's youth for serving in the armed forces is a rigorous study of age-related characteristics of this category. In order to study the readiness of young people aged 16 to 25 for military service in the Armed Forces of Ukraine on a volunteer basis an empirical study has been carried out. The following methods have been used in the research: the questionnaire "Adaptivity 200" providing the study of the level of social development and psychological qualities which are basic for adaptive personal processes; individual interviews and special questionnaires, aiming at determining the desire of young men to do military service. The research results have not revealed clear attitude (neither positive nor negative) towards the volunteer military service of the surveyed. It has been determined that the young people are easily influenced by other people's opinion and especially mass media and propaganda. Besides they are now fully aware in the specificity of the volunteer military service and are not psychologically ready for military service.

Keywords: psychological readiness for activity, social and psychological readiness of a recruit for volunteer military service, forced military service, professional psychological selection.

Подано до редакичії 01.03.2016

УДК: 159.923 .2

\author{
Анжела Станіславівна Харченко, \\ кандидат психологічних наук, доиент кафедри психології, \\ Полтавський національний педагогічний університету імені В. Г. Короленка, \\ вул. Остроградського, 2, м. Полтава, Украӥна
}

\section{ВИКЛАДАННЯ ПЕДАГОГІЧНОЇ ПСИХОЛОГІЇ: ВІД ТЕОРІЇ ДО ПРАКТИКИ}

Статтю присвячено питанням викладання педагогічної психології студентам педагогічного університету. Аналізуються прийоми активізації пізнавальної діяльності студентів при вивченні педагогічної психології (зіставлення підходів учених до проблеми, узагальнення викладачем висновку не до кіния, проблемні завдання $i$ питання, дискусії, аналіз конкретних ситуацій та інші). Обтрунтовується їх роль у підвищенні професійної компетентності студентів, а також в організації педагогічної взаємодіі.

Ключові слова: пізнавальна діяльність студентів, способи активізацї пізнавальної діяльності, лекиія, проблемна ситуачія в навчанні, діалогічна взаємодія, інтерес.

Постановка проблеми. Одним із важливих напрямків удосконалення вищої освіти в Україні є перехід $з$ предметного на особистісно зорієнтоване навчання. Метою такого навчання є особистість студен"Наука і освіта", №2-3, 2016 та, його професійні якості. Саме якісна вища освіта повинна забезпечити формування професійно грамотної особистості. Пріоритетними в цьому процесі мають бути демократизація і гуманізація відносин ви- 
кладача і студента, перетворення студента з об'єкта на суб'єкта навчальної роботи, вдосконалення змісту, форм і методів навчання студентів. Тому модернізація вищої освіти передбачає як озброєння студентів знаннями, так і створення умов для формування позитивного ставлення до цих знань, мотивів інтенсивного інтелектуального їх пошуку, творчого мислення i професійних умінь та навичок.

На сучасному етапі розвитку вищої освіти в Україні особливо актуальною є проблема активізації пізнавальної діяльності студентів педагогічного університету при вивченні навчальних дисциплін, зокрема, педагогічної психології.

Аналіз останніх досліджень і публікацій. Психологічні питання активізації пізнавальної діяльності тих, хто навчається, висвітлюють Б. Г. Ананьєв, О. П. Венгер, Л. С. Виготський, О. М. Леонтьєв, Н. Ф. Тализіна та інші. Встановлено, що неодмінною умовою розвитку якостей особистості $\epsilon$ включення тих, хто навчається, у самостійний творчий процес пізнання, розглянуті особливості різних видів пізнавальної діяльності, їх взаємозв'язок у процесі пізнання.

У дидактиці вищої школи як основний шлях активізації пізнавальної діяльності студентів розглядається розвиток пізнавальної активності студентів.

У працях психологів і педагогів пізнавальна діяльність визначається як «... свідоме виявлення активності індивіда, спрямоване на пізнання навколишньої дійсності, що здійснюється упродовж усього життя, у всіх видах діяльності і соціальних взаємостосунків, містить у своїй структурі мотиваційно-вольовий, процесуально-операційний і результативний компоненти та здійснюється за допомогою пізнавальних актів розуміння та рефлексії» [1, с. 185].

На думку О. П. Венгера [1], пізнавальна діяльність студентів є своєрідним акмеперіодом, що базується на всіх попередніх процесах біологічного, психологічного і соціального розвитку.

У психології студентській вік розглядається як період удосконалення володіння складними інтелектуальними операціями аналізу та синтезу, теоретичного узагальнення та абстрагування, аргументування. Причому когнітивні структури набувають складної будови, стають індивідуально своєрідними.

Активізація пізнавальної діяльності студентів розглядається психологами і педагогами як цілеспрямована діяльність викладача 3 метою стимулювання інтересу, підвищення активності, творчості, самостійності студентів у засвоєнні знань і застосуванні їх на практиці. Також активізація пізнавальної діяльності студентів визначається як уміння і прагнення творчо ставитися до навколишньої дійсності, що забезпечує успіх і додає навчальній праці студентів характер самостійного і творчого пошуку істини.

Мета статті полягає в аналізі способів активізації пізнавальної діяльності студентів педагогічного університету у процесі викладання педагогічної психології.

Виклад основного матеріалу дослідження. Метою викладання навчальної дисципліни «Педагогічна психологія» $є$ створення умов для осмислення та аналізу студентами власного емпіричного досвіду в освітніх системах; конструктивне узагальнення та освоєння аналітичного підходу до концепцій навчальної діяльності і формування особистості; розширення й уточнення образу професії і себе як фахівця.

При цьому основними завданнями вивчення дисципліни «Педагогічна психологія» $\epsilon$ ознайомлення студентів з етапами розвитку вітчизняної та зарубіжної педагогічної психології, іiї основними проблемами та методами; інтеграція та систематизація психологічних знань студентів про механізми ефективної організації освітнього процесу; формування уявлень студентів про основні теорії научіння, принципи та закономірності взаємозв'язку процесів навчання i розвитку психіки людини; формування у студентів умінь психологічного аналізу та прогнозування ефективності організації навчання, виховання учнів, а також ефективності професійно-педагогічної діяльності; сприяння становленню особистісної професійнопедагогічної позиції в аналізі й оцінці педагогічної діяльності фахівців різного профілю сучасних освітніх систем.

Важливо для активізації пізнавальної діяльності студентів на лекціях, практичних і лабораторних заняттях використовувати різноманітні методи і прийоми.

У процесі вивчення студентами педагогічної психології особлива увага приділяється підготовці і проведенню лекцій. Саме вони орієнтують студентів у проблемах педагогічної психології, дають змогу оцінити сучасні наукові досягнення в цій галузі. Мета лекцій полягає у формуванні знань студентів з основних проблем педагогічної психології, умінь аналізувати, синтезувати, порівнювати, класифікувати, узагальнювати отримані знання, а також - у вихованні особистісних якостей студентів. При проведенні лекцій $з$ педагогічної психології необхідно враховувати вікові та індивідуальні особливості студентів, закономірності їх пізнавальних та емоційно-вольових процесів. Широко використовуються лекції проблемного характеру, під час яких активізується пізнавальна діяльність студентів за допомогою проблемних питань, обговорень, мікродискусій тощо. Студент тоді приймає проблему, коли відчуває потребу в новому знанні i переконаний у тому, що способи пояснень, які він має, недостатні.

Крім того, проблемні ситуації, які створюються на лекціях, спонукають студентів засвоїти нові знання, способи чи умови виконання завдань. Створення проблемних ситуацій на лекціях пов'язується 3 інтересами і минулим досвідом студентів. Найбільш застосованими прийомами активізації мислення студентів під час лекцій з педагогічної психології $є$ співстав- 
лення, порівняння думок учених з певної проблеми, а також в процесі пояснення матеріалу виведення викладачем висновку не до кінця.

Завдяки використанню порівняння студенти визначають спільне і відмінне у поняттях, які формуються на лекції. Порівняння є важливим для розуміння цих понять. Виведення ж висновку викладачем не до кінця формує в студентів уміння узагальнювати.

Наведемо декілька фрагментів лекцій, де ці прийоми застосовуються окремо чи в комплексі.

Розглядаючи питання «Принципи традиційної та гуманістичної «центрованої на світі дитинства» парадигм освіти» (тема лекції «Освіта - глобальний об'єкт педагогічної психології»), проблемна ситуація створюється поетапно. Спершу у студентів формуються поняття про принципи традиційної парадигми освіти («субординація», «монологізм», «довільність», «контроль», «змужніння», «ініціація», «деформація») і гуманістичної («рівність», «діалогізм», «співіснування», «свобода», «співрозвиток», «єдність», «взаємоприйняття»). Всі принципи обгрунтовуються, наводяться факти, докази, приклади, які вказують на протиріччя $\mathrm{i}$ у принципах, і у парадигмах освіти загалом.

Під час діалогічної взаємодії зі студентами робиться висновок про те, що розглянуті принципи гуманістичної освітньої парадигми являють собою деяку ідеалізовану, доки не зовсім реалістичну модель освіти. На наступному етапі студентам ставиться таке питання: «Чому неможлива повна орієнтація батьків і вчителів на таку особистість, що саморозвивається, згідно з принципом «свободи», який пропонує гуманістична парадигма освіти?» Студенти доходять висновку, що такій особистості важко адаптуватися та інтегруватися в референтній для неї групі. Наступне питання студентам: «За яких умов реалізація гуманістичної парадигми освіти можлива?» Студенти узагальнюють: «Реалізація принципів гуманістичної парадигми освіти передбачає обов'язкове врахування принципу реальності».

При викладенні «Теорії морального розвитку особистості» (тема лекції «Психологічні особливості морального розвитку особистості») студенти знайомляться $з$ різними підходами до цієї проблеми. Розглянувши теорію Ж. П'яже, вони мають відповісти на питання: «Чи обов'язково кожна дитина проходить спершу стадію «Етика примусу», а потім стадію «Етика співробітництва»?» Обгрунтовуючи різні варіанти відповіді на питання, студенти висловлюють думки про те, що діти й підлітки з метою пошуку справедливості можуть орієнтуватися на авторитетну для них людину; що і діти, і дорослі можуть підкорятися правилам, законам не за власним бажанням, а щоб запобігти покарання. Тому студентами робиться висновок, що і діти, $\mathrm{i}$ дорослі можуть не дійти до автономії («Етика співробітництва»). Адже вони не засвоїли існуючі правила, не сприйняли їх як власні і залишились на доморальному рівні («Етика примусу»).

"Наука і освіта", №2-3, 2016
На наступному етапі роботи, ознайомившись 3 теорією морального розвитку особистості за Л. Кольбергом, студенти порівнюють зміст стадій, запропонованих цим ученим і Ж. П'яже. Студенти переконуються в існуванні схожості - дві стадії за Ж. П'яже тотожні трьом стадіям (не рівням!) за Л. Кольбергом. Для обміркування теорії Л. Кольберга студентам пропонується низка питань: «Чи завжди вчинок людини повинен оцінюватись як правильний, якщо він продиктований совістю - незалежно від його законності чи думки інших людей? Чому?», «Хто більше підкоряє свою поведінку етичним принципам: діти чи дорослі? Чому?», «Чи завжди люди, що знаходяться на одному й тому ж рівні морального розвитку, під тиском обставин діють однаково? Чому?». Після обговорення відповідей на питання студентам пропонується жіноча концепція моральності К. Гілліган. Ознайомившись 3 відмінностями в моральних судженнях чоловіків і жінок, студентам ставиться питання: «Які ж існують підстави, щоб вважати рівень моральних суджень жінок нижчим за чоловічий?» У результаті дискусії студенти встановлюють, що мають місце дві лінії розвитку моральної свідомості. Одна 3 них акцентує увагу на логіці, справедливості, інша на особистісних стосунках і турботі. І чоловіки, і жінки демонструють обидві лінії, хоча одна може домінувати у певної статі. Студентам пропонується таке питання: «Яку ж людину ми можемо назвати високоморальною?» Студенти узагальнюють, що висока моральність передбачає як чоловічу орієнтацію на захист прав і справедливості, так і властиву жінкам відповідальність і турботу про ближніх.

Отже, застосовувані прийоми активізації пізнавальної діяльності допомагають розв'язати теоретичні проблеми педагогічної психології, а також орієнтують студентів у практичних професійних проблемах.

Для активізації пізнавальної діяльності студентів під час лекцій використовуються епізоди з біографій, наукової діяльності вчених, наводяться характеристики їх особистісних особливостей. Так, формуючи знання студентів про історію розвитку педагогічної психології, наводяться факти з біографії творця теорії розвитку вищих психічних функцій Л. С. Виготського. За надзвичайне захоплення веденням дискусій, історичною, художньою літературою та поезією ще в підлітковому віці серед друзів він отримав прізвисько «юний професор». Згодом, працюючи у Московському Інституті психології, коли він читав лекції, студенти стояли під стінами сповнених аудиторій і слухали його через відкриті вікна. Якщо Л. С. Виготський збирався у відрядження, студенти писали йому поеми, бажаючи вдалої подорожі. Проте, відчуваючи, що життя триватиме не довго, він працював надзвичайно швидким темпом. Учений не тільки встигав писати, читати лекції й проводити дослідження, але й відвідував багато клінік країни, допомагаю- 
чи лікувати дорослих і дітей, що страждали на неврологічні хвороби [2].

Студентам цікаво дізнатися, що швейцарський психолог Ж. П'яже у 10 років опублікував першу наукову роботу про горобців-альбіносів, за якими декілька років спостерігав у парку. Коли йому виповнилося 15 років, його запросили на роботу до Женевського музею, а в 21 рік присвоїли ступінь доктора природничих наук. Близько 50 років учений провів у власному будинку в Альпах, узагальнюючи результати своїх досліджень, кожного року восени спускався з гір, щоб передати матеріали для публікацій [5].

Під час розгляду питання про особливості програмованого навчання (тема лекції «Основні напрямки навчання в сучасному світі») звертається увага студентів на індивідуальні особливості особистості Б. Ф. Скіннера. Не дивлячись на успішну наукову кар'єру, вчений захоплювався майструванням різних речей. Коли народилась перша дитина, він вирішив зробити удосконалене дитяче ліжечко (його інколи називають «бебі-бокс» Скіннера). Воно мало спеціальний пристрій, який його підігрівав. Це дозволило менше закутувати дитину і надавати ій можливість більше рухатися [2].

Аналізуючи підходи до вивчення мотивів навчання школярів (тема лекції «Психологія учіння як специфічної форми пізнавальної діяльності людини»), акцентується увага студентів на дослідженнях таких учених, як О. Я. Чебикін та В. Ф. Моргун, які вказують, що мотивувати позитивне ставлення до навчального предмета може як його зміст, так і метод роботи з ним.

Особливої уваги заслуговують дані про необхідність під час лекцій використовуються мультимедійні технології. Вони дозволяють об'єднати в комп'ютерній системі текст, звук, відеозображення, графічне зображення та анімацію (мультиплікацію).

Як уже зазначалося, ефективними прийомами активізації пізнавальної діяльності студентів на практичних заняттях $є$ проблемні завдання і питання. Використання останніх сприяє застосуванню набутих студентами знань у нових умовах. Наприклад, під час закріплення знань студентів про структуру навчальної діяльності створюються такі проблемні ситуації, коли $€$ невідповідність між словесним описом процесу, предмета чи механізму та їх умовно-графічним зображенням.

Відомо, що проблемні питання забезпечують осмислення і закріплення теоретичних знань, вироблення умінь застосовувати ці знання студентами у майбутній професійній діяльності. Наприклад, на практичному занятті при закріпленні знань основних напрямків навчання в світі студентам ставиться таке проблемне питання: «В якому з основних напрямків навчання розв'язується проблема швидкого й одночасно творчого засвоєння знань?».

Як показали наші спостереження, досить ефективним методом навчання у вищій школі, що активізує пізнавальну діяльність студентів, є дискусія. На практичному занятті, присвяченому з'ясуванню психологічних особливостей агресивності особистості, використовується прийом дискусії з розподіленими ролями. До проведення заняття визначається дві підгрупи студентів, які готуються до викладення спірних думок 3 приводу впливу екранного насильства на особистість дитини. Після дискусії в обговоренні беруть участь інші студенти. Всі мають висловлюватись одноразово. Цей прийом формує вміння студентів дискутувати та узагальнювати факти.

Відомо, що під час лабораторних занять у студентів формуються вміння діагностувати суб' єктивне ставлення учнів до школи, рівень мотивації навчання школярів, педагогічні здібності, педагогічну спрямованість учителя, вихованість школярів, батьківське ставлення, а також надавати кваліфіковані рекомендації.

Крім того, ефективним прийомом активізації пізнавальної діяльності студентів $є$ аналіз конкретних ситуацій. Останні включають як певну інформацію, так і проблему, що потребує вирішення. Використовується моделювання педагогічних ситуацій і наступне їх обговорення. План обговорення включає виділення помилки, короткі ілюстративні приклади, помилкові переконання, корекцію осмислення, корекцію поведінки. Наприклад, аналіз помилки вчителя «Не робити помилок» (тема практичного заняття «Психологія педагогічної діяльності»). Моделюється така ситуація: під час виведення хімічної формули вчитель припустився помилки; учень указав на неї; учитель зніяковів; він стурбований тим, що подумають про нього учні.

Обговорюючи ситуацію, студенти наводять помилкові переконання вчителя: помилки означають слабкість, незнання; якщо припустився помилки, то приховай це тощо. Корекція осмислення полягає у з'ясуванні помилковості переконань: помилки допустимі, оскільки помилитися може кожний; бажання бути завжди правим веде до внутрішньої напруги, примушує приховувати свої «помилки», що робить учителя знервованим і агресивним; через відстоювання своєї правоти, не виправивши помилку, ризик втрати авторитету. Корекція поведінки включає використання вчителем таких прийомів: «Молодець, що ти помітив помилку. Я припустився іiі навмисно. Хотів подивитися, хто неуважний», «Помилка є неістотною, я зробив іiі випадково», «Вибачте, я помилився. Виправте в себе в зошитах» та інші. Також слід пам'ятати, що більшість учнів, хто помітив помилку і побачив, що вчитель не боїться помилитися, проникнуться симпатією до нього. Вчителю необхідно коротко описувати кожен випадок, коли він «упіймав» себе на приховуванні помилки чи відмові виконати щось у разі побоювання помилитися. Наприкінці кожного тижня підбивати підсумок [4].

Для активізації пізнавальної діяльності студентів при вивченні педагогічної психології використовуються різні форми їх самостійної роботи. Кожне прак- 
тичне і лабораторне заняття передбачає конспектування першоджерел, роботу 3 підручниками і посібниками, що вимагає володіння прийомами роботи 3 навчальним матеріалом. Як свідчить досвід роботи, студенти другого і навіть третього курсу навчання прагнуть запам'ятати матеріал без достатнього розуміння і не використовують прийомів, які б оптимізували процес засвоєння знань. Тому на кожному занятті, крім питань 3 обговорюваної проблеми, студентам пропонуються й такі: «Як подати у вигляді плану, схеми відповідь на питання?» або: «Які мнемотехнічні прийоми можна використати, щоб запам'ятати, скажімо, види навчальних дій?»

Як засвідчили отримані результати дослідження, досить ефективними у цьому процесі виступають індивідуальні науково-дослідні завдання для студентів, що передбачають складання презентації до однієї 3 тем дисципліни «Педагогічна психологія». Зміст презентації повинен відображати розкриття теми, обгрунтованість поділу на слайди, наявність графічного оформлення (фотографій, малюнків, діаграм), грамотність викладу, наявність цікавої додаткової інформації.

Висновки та перспективи подальших розвідок. Таким чином, викладання педагогічної психоло-

\section{ЛIТЕРАТУРА}

1. Венгер О. П. Психолого-педагогічні особливості розвитку пізнавальної діяльності студентів вищого навчального закладу: дис. ... кандидата психол. наук : 19.00.07 / О. П. Венгер. - Острог, 2014. - 225 с.

2. Крэйн У. Теории развития. Секреты формирования личности / У. Крэйн. -5-е международное издание. - СПб. : прайм - ЕВРОЗНАК, 2002. - 512 с.

3. Моргун В. Поетична психологія та психологічна поезія. Творча зустріч у поетичній лабораторії психолога 27 травня 2014 р. / В. Моргун; організатор і ведуча М. Лагода. - Полтава : ПНПУ імені

\section{ЛIТЕРАТУРА}

1. Vengher, O. P. (2014). Psykhologhopedaghoghichni osoblyvosti rozvytku piznavalnoi diialnosti studentiv vyshhoho navchalnoho zakladu [Psychological and Pedagogical features of development of cognitive activity of students of higher educational institutions]. Candidate's thesis. Ostroh [in Ukrainian].

2. Kreyn, U. (2002). Teorii razvitiya. Sekrety formirovaniya lichnosti [Theories of development. Secrets of the formative personality]. Saint Petersburg: praym EVROZNAK [in Russian].

3. Morghun, V. (2014). Poetychna psykholohiia ta psykholohichna poeziia. Tvorcha zustrich u poetychnii laboratorii psykholoha 27 travnja 2014 r. [Political psychology and psychological poetry. The creative гії найбільш ефективно реалізується при застосуванні комплексу різних методів, засобів та прийомів. Показано, що найбільш дієвими в активізації пізнавальної діяльності виступають: на лекціях - проблемні ситуації, порівняння фактів, автобіографічних даних вчених тощо; на лабораторно-практичних заняттях дискусії, моделювання ситуацій, розгляд реальних проблем із визначенням шляхів їх вирішення та ін.

Установлено, що комплекс застосованих прийомів активізації пізнавальної діяльності студентів дозволяє здійснити перехід від педагогічної психології як джерела інформації до педагогічної психології як джерела спілкування, від вузьконавчальних завдань до професійно орієнтованих, від суб'єкт-об'єктних відносин викладача і студента до педагогічної взаємодії й співтворчості.

Серед проблем, які вимагають подальшого дослідницького пошуку, слід виділити детермінанти розвитку пізнавальної діяльності студентів. Також являє інтерес створення нових методів розвитку та розробка тренінгових технологій формування пізнавальної діяльності студентів педагогічного університету.

В.Г.Короленка. - ПОУНБ імені І. П. Котляревського, 2014. -65 c.

4. Реан А. А. Социальная педагогическая психология / А. А. Реан, Я. Л. Коломинский. - СПб. : Издательство «Питер», 2000. - 416 с.

5. Хьелл Л. Теории личности / Л. Хьелл, Д. Зиглер. - 3-е издание. - СПб. : Питер. - 2011. - 608 c.

6. Чебыкин А. Я. Эмоциональная регуляция учебно-познавательной деятельности (второе издание): монографія / А. Я. Чебыкин. - Одесса. - 1991. - 167 с.

meeting is in the poetic laboratory of psychologist, May, 27, 2014]. Poltava : PNPU imeni V.Gh.Korolenka. POUNB imeni I. P. Kotliarevskoho [in Ukrainian].

4. Rean, A.A., \& Kolominskiy, Ya.L. (2000). Sotsialnaya pedagogicheskaya psikhologiya [Social pedagogical psychology]. Saint Petersburg: izdatelstvo «Piter» [in Russian].

5. Khiell, L., \& Zigler, D. (2011). Teorii lichnosti [Theories of personality]. Saint Petersburg: Piter [in Russian].

6. Chebykin, A. Ya. (1991). Emotsionalnaya regulyatsiya uchebno-poznavatelnoy deyatelnosti (vtoroe izdanie): monografiya [Emotional regulation of cognitive activity: monograph]. Odessa [in Russian]. 


\section{Анжела Станиславовна Харченко, кандидат психологических наук, дочент кафедры психологии, Полтавский национальный педагогический университет имени В. Г. Короленко, ул.Остроградского, 2, г. Полтава, Украина}

\section{ПРЕПОДАВАНИЕ ПЕДАГОГИЧЕСКОЙ ПСИХОЛОГИИ: ОТ ТЕОРИИ К ПРАКТИКЕ}

Статья посвящена вопросам преподавания педагогической психологии студентам педагогического университета. В ней обосновывается, что важным направлением усовершенствования высшего педагогического образования в Украине является переход от предметного к личностно ориентированному обучению. Целью такого обучения является личность студента, его профессиональные качества. Именно качественное высшее образование должно обеспечить формирование профессионально грамотной личности. Приоритетными в этом процессе должны быть демократизация и гуманизация отношений преподавателя и студентов, а также совершенствование содержания, форм и методов обучения студентов. Цель статьи заключается в анализе способов активизации познавательной деятельности студентов педагогического университета в процессе преподавания педагогической психологии. Обосновывается их роль в повышении профессиональной компетентности студентов, а также в организации педагогического взаимодействия. На основе анализа научной литературы выявлено, что познавательная деятельность определяется как сознательное проявление активности индивида, направленное на познание окружающей действительности, которое осуществляется на протяжении всей жизни во всех видах деятельности и социальных взаимоотношений, состоит из мотивационно-волевого, процессуально-операционного и результативного компонентов и осуществляется с помощью познавательных актов понимания и рефлексии. Особый интерес для нашего исследования представляет вывод о том, что активизация познавательной деятельности студентов рассматривается психологами и педагогами как целенаправленная деятельность преподавателя с целью стимулирования интереса, повышения активности, творчества, самостоятельности студентов в усвоении знаний и применении их на практике; как умение и стремление творчески относиться к окружающей действительности, которая обеспечивает успех и добавляет учебному труду студентов характер самостоятельного и творческого поиска истины. При обучении педагогической психологии эффективными приемами активизации познавательной деятельности студентов являются следующие: сопоставление подходов ученых к проблеме, обобщение преподавателем вывода не до конца, проблемные задания и вопросы, дискуссии, анализ конкретных ситуаций. Также для активизации познавательной деятельности студентов используются индивидуальные научно-исследовательские задания, которые предполагают создание презентации к одной из тем учебной дисциплины. Приемы активизации познавательной деятельности студентов позволяют осуществить переход от педагогической психологии как источника информации к педагогической психологии как источнику общения, от узкоучебных заданий к профессионально ориентированным, от субъект-объетных отношений преподавателя и студента к педагогическому взаимодействию и сотворчеству.

Ключевые слова: познавательная деятельность студентов, способы активизации познавательной деятельности, лекция, проблемная ситуация в обучении, диалогическое взаимодействие, интерес.

\section{Anzhela Kharchenko, \\ PhD (Candidate of Psychological Sciences), associate professor, Department of Psychology, Poltava V. G. Korolenko National Pedagogical University, 2, Ostrohradskoho Str., Poltava, Ukraine}

\section{TEACHING PEDAGOGICAL PSYCHOLOGY: FROM THEORY TO PRACTICE}

The article deals with the problem of teaching pedagogical psychology to students of Pedagogical Universities. It is proved that one of the most important directions of improvement of higher education in Ukraine is the transition from the subjective to the person-oriented studying. The aim of this studying is the personality of a student and his/her professional qualities. The qualitative higher education should ensure the formation of a professionally competent person. The democratization and humanization of the relationships of a lecturer and his/her students, as well as the improvement of the content, forms and methods of teaching of students, should be the priority direction in this process. The article is aimed at reviewing the ways of activating cognitive activity of pedagogical university students in the process of teaching pedagogical psychology to them. The role of the methods in enhancing of students' professional competence, as well as in the organization of pedagogical interaction between a lecturer and students, is substantiated. The review of scientific literature has shown that cognitive activity is defined as the conscious activity, which is aimed at studying the reality. It is carried throughout the whole life in all kinds of activities and social relations. It consists of motivational-volitional, procedural, operational and effective components and is held with the help of cognitive acts of understanding and reflection. The activation of students' cognitive activity is considered by psychologists and pedagogues as a focused activity of a teacher in order to stimulate interest, to increase activity, creativity and independence of students in the mastering of knowledge and their application in practice. It is also seen as the creative attitude towards 
the reality, which provides success and gives the nature of independent and creative search for the verity to the student's learning. There are effective methods of activation of students' cognitive activity while teaching pedagogical psychology to them: the comparison of approaches to the problem, lecturer's uncompleted generalization of conclusions, problematic tasks and questions, discussions, analysis of specific situations. Also individual research tasks are used for the activation of student's cognitive activity. They involve creating presentations on one of the topics of subject. Methods of activation of students' cognitive activity allow to make the transition from pedagogical psychology as a source of information to pedagogical psychology as a source of communication, from narrow educational tasks to professionallyoriented ones, from the subject-objective relationships of a lecturer and students to pedagogical interaction and cocreation.

Keywords: students' cognitive activity, methods of activation of cognitive activity, lecture, problematic situation in teaching, dialogic interaction, interest.

Подано до редакиії 01.03.2016 